Lord Brain, while Dr. K. W. Cross explains how Head's collaboration with Hering at Prague later lod to the discovery of his paradoxical reflex. Head's considerable contribution to our knowledge of sensation is examined by Dr. R. A. Henson, while his theories of aphasia are analysed by Dr. Macdonald Critchley. The symposium also includes a detailed bibliography of Head's original works.

\section{U.K. Atomic Energy Authority}

The United Kingdom Atomic Energy Authority has announced the following senior appointments: in the Production Group, Mr. S. F. Hines, formerly general manager, Capenhurst, is appointed production director, with his headquarters at Risley, and Mr. W. R. A. Taylor, formerly deputy general manager, is appointed general manager, Capenhurst, to succeed Mr. Hines; in the Reactor Group, Mr. P. W. Mum. mery is appointed deputy director, Atomic Energy Establishment, Winfrith. These appointments took effect from April 1.

\section{S. F. Hines, O.B.E.}

Mr. Hines was educated at St. Albans School and the University of London. In 1930 he joined the staff of the Royal Gunpowder Factory, Waltham Abbey, and in 1936 transferred to the Royal Ordnance Factory, Irvine. In 1939 he was appointed superintendent of the Factory at Pembrey, and in 1944 became superintendent of the Factory at Drigg, Sellafield and Bootle. In $1946 \mathrm{Mr}$. Hines was appointed general manager of the Atomic Energy Factory at, Springfields and was responsible for starting up this plant for uranium purification and fuel element manufacture. In $1950 \mathrm{Mr}$. Hines became general manager of the new gaseous diffusion plant at Capenhurst.

W. R. A. Taylor, O.B.E.

Mr. TAYLor was educated at Scunthorpe Grammar School and the University of Cambridge. During the War he was a member of the Directorate of Filling Factories, becoming chief technical assistant in 1945 . In 1946 he joined the Department of Atomic Energy at Risley and in 1954 was appointed works manager, Springfields Works. In 1956 Mr. Taylor was appointed deputy general manager, Capenhurst Works (gaseous diffusion plant). In July 1956 he was a member of the Duke of Edinburgh's study conference.

P. W. Mummery, O.B.E.

Mr. Mummery was educated at Rotherham Grammar School during 1936-44 and Queen's College, Cambridge, 1944-47. He joined the Authority in August 1947 as a scientific officer at Harwell. On January 1, 1952, he was promoted to senior scientific officer, Atomic Energy Research Establishment, Harwell, in 1955 to principal scientific officer, and in 1957 to senior principal scientist. Mr. Mummery later became head of the Power Reactor Branch, Reactor Division, Harwell, and is at present head of Industrial Power Reactor Division, Atomic Energy Establishment, Winfrith, Dorset.

Reorganization of Radio Standards Laboratory at the U.S. National Bureau of Standards

The Radio Standards Laboratory at the Boulder Laboratories of the National Bureau of Standards, U.S. Department of Commerce, has been divided into a Radio Standards Division and a Circuit Standards Division to provide unified direction for a growing programme. Dr. J. M. Richardson will continue as head of the Radio Standards Laboratory, which is responsible for providing the central basis for the complete, consistent, uniform and accurate measurement of physical quantities pertaining to radio science, and assurance of international co-ordination of such measurements. Dr. Y. Beers, chief of the Radio Physics Division, will direct research concerning the interaction of electromagnetic fields with matter having possible application to radio standards, froquency standards, time scales, atomic and aggregate properties of matter, and constants of physics. The Division will also develop certain national standards and direct the dissemination and international co-ordination of the results. The Circuit Standards Division, headed by Dr. G. E. Schafer, will conduct research and develop national standards of physical quantities pertaining to radio circuits and measurement techniques, disseminate the standards, especially by calibration services, and direct their international co-ordination.

\section{The Iron and Steel Institute}

THe following changes have been announced by the Council of the Iron and Steel Institute: Honorary Vice-President, Mr. D. A. Oliver (director of research, B.S.A. Group of Companies); Vice-President, $\mathrm{Mr}$. E. W. Senior (director, British Iron and Steel Federation); Members of Council, Dr. N. P. Allen (superintendent, Metallurgy Division, National Physical Laboratory), and Sir Douglas Bruce-Gardner (deputychairman, G.K.N. Steel Company, Ltd., and joint, managing director, Lysaghts Scunthorpe Works); Additional Honorary Members of Council, Mr. A. Jackson (technical adviser on steelmaking, United Steel Companies, Ltd.), and Prof. F. D. Richardson. (professor of extraction metallurgy, Imperial College of Science and Technology).

Awards

THE Council of the Iron and Steel Institute has made the following awards: Bessemer Gold Medal for 1962, Sir Charles Goodeve, director of the British Iron and Steel Research Association, president during 1961-62 of the Institute; Sir Robert Hadfield Medal for 1962 , Mr. G. T. Harris, assistant managing director, Jessop-Saville, Ltd.; Williams Prizes, Mr. H. I. A. Archibald (Stewarts and Lloyds, Ltd.) for the paper "The Application of a Digital Computer to the Pre-operational Problems of Programming the Extraction and Supply of Iron Ore", and Mr. M. C. Harrison and Mr. P. Truscott (Steel Company of Wales, Ltd.) for the paper "Operation of the Oxygen/ Steam-blown Converters at the VLN Steel Plant of the Steel Company of Wales, Ltd."; Andrew Carnegie Silver Medal for 1961, Mr. J. S. White (Univorsity of Liverpool) for the papers "Kinetic Features of Upper and Lower Bainite Formation in a Plain Carbon and a 3 per cent Ni-Cr Steel" and "Tho Effect of Upquenching on the Kinetics of Bainite Formation".

\section{International Co-operation in Outer Space}

The U.S.S.R. has nominated Prof. V. A. Bugaev and the United States has nominated Dr. M. Alaka to be consultants to the Secretary-General of the World Meteorological Organization in studies related to the preparation of a report on global benefits to be derived from meteorological satellite rosearch. These two scientists began work in Geneva on March 13,1962 . This co-operation between the world's two leading countries on research in outer space results from a resolution of the General Assembly of the 